\title{
Comparison of beaching slopes from two centrally discharging tailings storage facilities
}

\author{
P.C. Addis Golder Associates Africa (Pty) Ltd, South Africa \\ E.J. Cunningham Golder Associates Africa (Pty) Ltd, South Africa
}

\begin{abstract}
This paper investigates the beaching slopes of two centrally discharging tailings storage facilities (TSF). It explains the methodology for determining the beaching angles and how this information was used in modelling the remaining life. It then examines the properties of the tailings from the two facilities and discusses the effects of these properties on the beaching slopes.
\end{abstract}

\section{Introduction}

Golder Associates Africa have recently been involved in two projects that have required the determination of beaching profiles for centrally discharging tailings storage facilities. Once the beaching profiles had been determined they were used to model the final surface of the facilities and hence determine the requirements for perimeter embankment raises. The two facilities have very different profiles and the reasons for this are examined.

\section{$2 \quad$ Site details}

\subsection{Description of Site A}

Site $\mathrm{A}$ is a storage facility for fines, i.e. $<0.3 \mathrm{~mm}$ from a diamond processing plant. It was originally intended to be a facility for short term surface disposal after which the fines would be used to backfill the mined out open pits. Due to ongoing underground mining operations, the backfilling option was not feasible. The footprint of the facility was therefore increased to approximately $410 \mathrm{Ha}$ and perimeter embankments were constructed with calcrete. The facility has two discharge towers which were originally located within two disused paddocks. Riser A is located on the southern perimeter of the southern paddock and Riser B is located centrally within the northern paddock. On the eastern side of the facility there are three conventional tailings storage facilities and to the west there is a course residue facility. There is no return water dam associated with the facility and excess water is stored on the facility, discharged into evaporation ponds or pumped back to the plant. Although the slurry has a relatively low density (53 to $55 \%$ solids by mass), it is sufficiently high to prevent separation of water and solids after discharge. An aerial photograph of the facility is shown in Figure 1. 


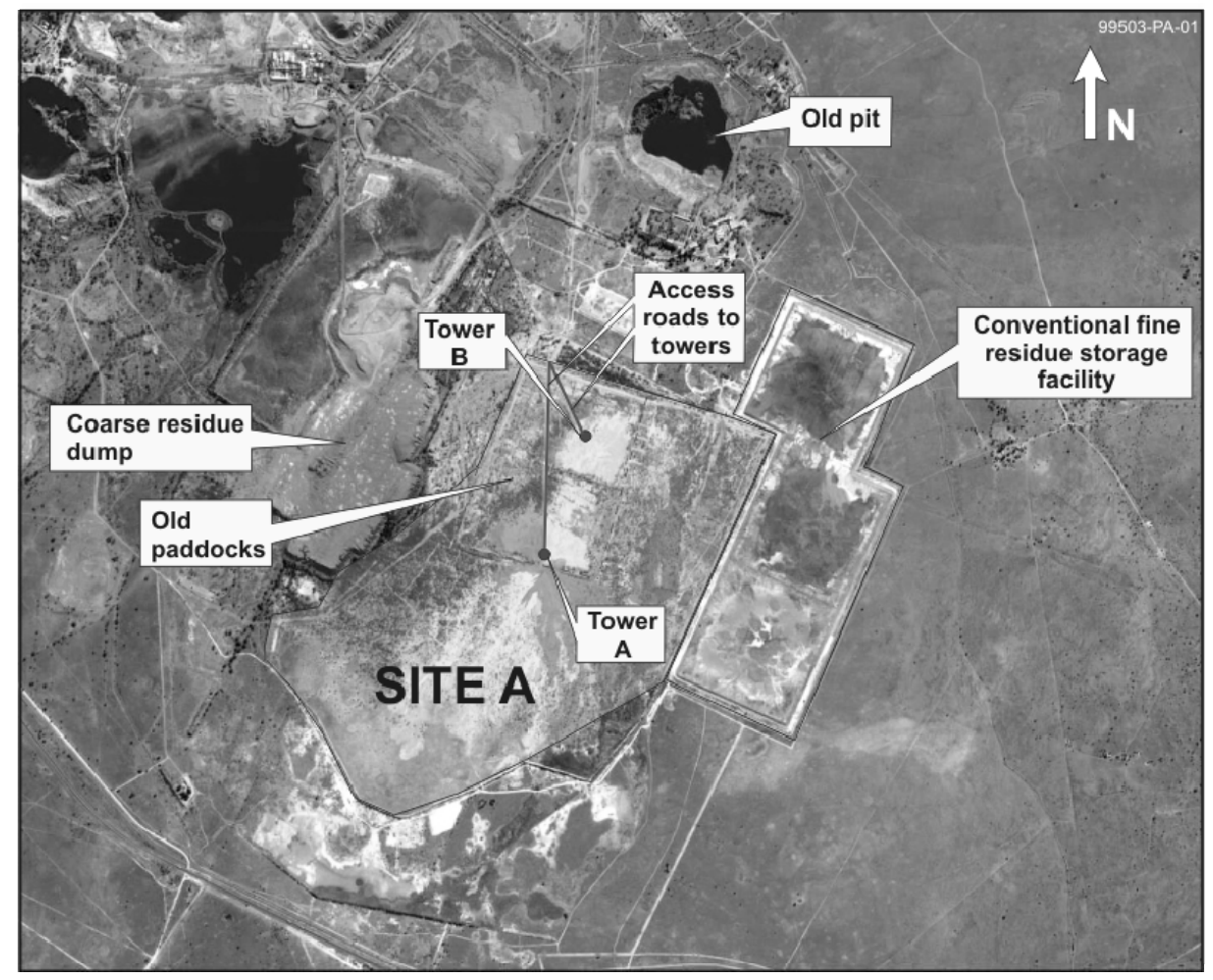

Figure 1 Layout of Site A

\subsection{Description of Site B}

Site B is a tailings storage facility for fines from a gold processing plant. The TSF consists of two adjacent cells that have a combined footprint of $45 \mathrm{Ha}$. Each cell has five discharge towers. An initial $3 \mathrm{~m}$ high perimeter embankment was constructed with compacted laterite. A subsequent $5 \mathrm{~m}$ high raise with tailings has been completed around the full perimeter. The TSF has an adjacent lined sediment pond and two return water dams. A site layout of the facility is shown in Figure 2.

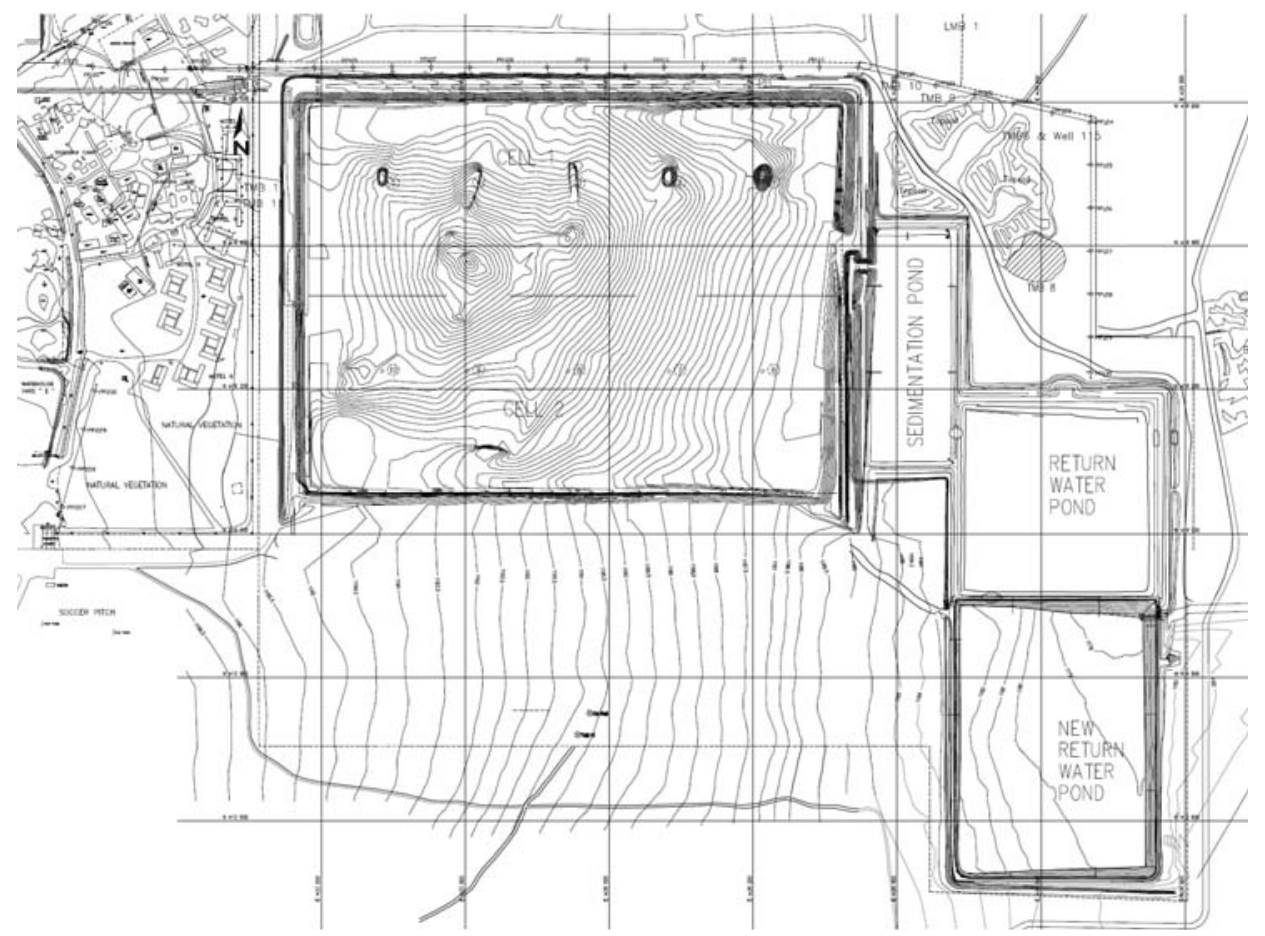

Figure 2 Layout of Site B 


\subsection{Technical comparison}

Details of the two sites are provided in Table 1 below.

Table 1 Site details

\begin{tabular}{|c|c|c|c|}
\hline Parameter & Units & Site A & Site B \\
\hline Location & & $\begin{array}{l}\text { Northern Cape, South } \\
\text { Africa }\end{array}$ & Kahama District, Tanzania \\
\hline Life of mine & & 2016 & 2036 \\
\hline Elevation & mamsl & 1,200 & 1,185 \\
\hline Mean annual precipitation & $\mathrm{mm}$ & 395 & 875 \\
\hline Mean annual evaporation & $\mathrm{mm}$ & 2,060 (S pan) & $1,700(\mathrm{~A} \mathrm{Pan} \times 0.7)$ \\
\hline $\begin{array}{l}1 \text { in } 50 \text { year } 24 \text { hour storm } \\
\text { depth }\end{array}$ & $\mathrm{mm}$ & 91 & 199 \\
\hline Footprint area & $\mathrm{Ha}$ & 407 & 45 \\
\hline Delivery towers & No. & 2 & 10 \\
\hline Deposition rate & $\begin{array}{l}\text { tonnes per } \\
\text { month }\end{array}$ & $\begin{array}{l}\text { Design: } 270,000 \\
\text { Current: } 104,000\end{array}$ & $\begin{array}{l}\text { Design: } 70,000 \\
\text { Current: } 65,000\end{array}$ \\
\hline Specific gravity & ratio & 2.74 & 2.79 \\
\hline Slurry density & $\mathrm{t} / \mathrm{m}^{3}$ & 1.5 & 1.9 \\
\hline$\%$ Solids by mass & $\%$ & 53 to 55 & 73 to 75 \\
\hline $\begin{array}{l}\text { Average particle size } \\
\text { distribution }\end{array}$ & & $\begin{array}{l}\% \text { Gravel }=0 \text { to } 2 \% \\
\% \text { Sand }=43 \text { to } 50 \% \\
\% \text { Silt }=35 \text { to } 40 \% \\
\% \text { Clay }=12 \text { to } 17 \%\end{array}$ & $\begin{array}{l}\% \text { Gravel }=0 \% \\
\% \text { Sand }=20 \text { to } 28 \% \\
\% \text { Silt }=58 \text { to } 72 \% \\
\% \text { Clay }=8 \text { to } 14 \%\end{array}$ \\
\hline
\end{tabular}

It is apparent from Table 1 that the main differences between the two sites are the scale and the percentage solids. Site B can be considered an ultra high density paste while Site A could be considered thickened tailings.

\subsection{Deposition control}

The operation of the two facilities has illustrated the importance of being able to control the direction of deposition. As with conventional tailings disposal, paste disposal requires cycled deposition in layers. Originally both facilities used variations of the Robinsky cone deposition method. This method has the disadvantage of preferential flow paths being developed which inhibits the ability to deposit in layers and reduces consolidation and desiccation. Site A has developed a 'wagon wheel' deposition method. This allows for deposition in eight different directions and has resulted in improved beach slopes and consolidation.

The paste on Site B consolidates rapidly and can be walked on within a few days of deposition. Access to the surface of the facility has allowed for the extension of the deposition pipe on the surface of the facility. The location of the deposition point is then changed by man handling the outlet pipe. This method has enabled the establishment of intermediate deposition points i.e. between the deposition towers and resulted in increased storage capacity. The facility is well managed and the operators have managed to increase the elevation of the intermediate points above that of the deposition towers. 


\section{Beaching slopes}

The methodology adopted for determining the average beaching slopes was as follows:

- a number of cross sections were taken through the deposition points (or highest point for Site B) of the two facilities

- the sections were plotted on one set of axis with a vertical scale exaggeration

- a composite curve based on the average beaching slopes was determined.

The composite curves for Site A are provided in Tables 2. The average profiles for tower A and B were used. Tower B has a shorter beach but this had a minimal effect on the beach profile. The maximum beach length for Site A is $1,600 \mathrm{~m}$.

Table 2 Composite curve of beaching slopes for Site A

\begin{tabular}{ll}
\hline $\begin{array}{l}\text { Distance From } \\
\text { Deposition Point }\end{array}$ & $\begin{array}{l}\text { Slope (Vertical: } \\
\text { Horizontal) }\end{array}$ \\
\hline 0 to $50 \mathrm{~m}$ & $1: 20$ \\
$50 \mathrm{~m}$ to $100 \mathrm{~m}$ & $1: 36$ \\
$100 \mathrm{~m}$ to $200 \mathrm{~m}$ & $1: 50$ \\
$200 \mathrm{~m}$ to $400 \mathrm{~m}$ & $1: 90$ \\
$400 \mathrm{~m}$ to $800 \mathrm{~m}$ & $1: 120$ \\
$800 \mathrm{~m}$ to $1,400 \mathrm{~m}$ & $1: 190$ \\
$>1,400 \mathrm{~m}$ & $1: 300$ \\
\hline
\end{tabular}

The composite curve beach slopes for Site B are provided in Table 3. The maximum beach length for Site B is $600 \mathrm{~m}$.

Table 3 Composite curve of beaching slopes for Site B

\begin{tabular}{ll}
\hline $\begin{array}{l}\text { Distance From } \\
\text { Deposition Point }\end{array}$ & $\begin{array}{l}\text { Slope (Vertical: } \\
\text { Horizontal) }\end{array}$ \\
\hline 0 to $30 \mathrm{~m}$ & $1: 11$ \\
$30 \mathrm{~m}$ to $180 \mathrm{~m}$ & $1: 16$ \\
$180 \mathrm{~m}$ to $330 \mathrm{~m}$ & $1: 18$ \\
$>330 \mathrm{~m}$ & $1: 32$ \\
\hline
\end{tabular}

Using the data in Tables 2 and 3, design profiles for the surface of the TSF's can be developed. A graphical comparison of the composite curves over the first $600 \mathrm{~m}$ of deposition is provided in Figure 3 . Note that the figure has an exaggerated vertical scale of ten times the horizontal. 


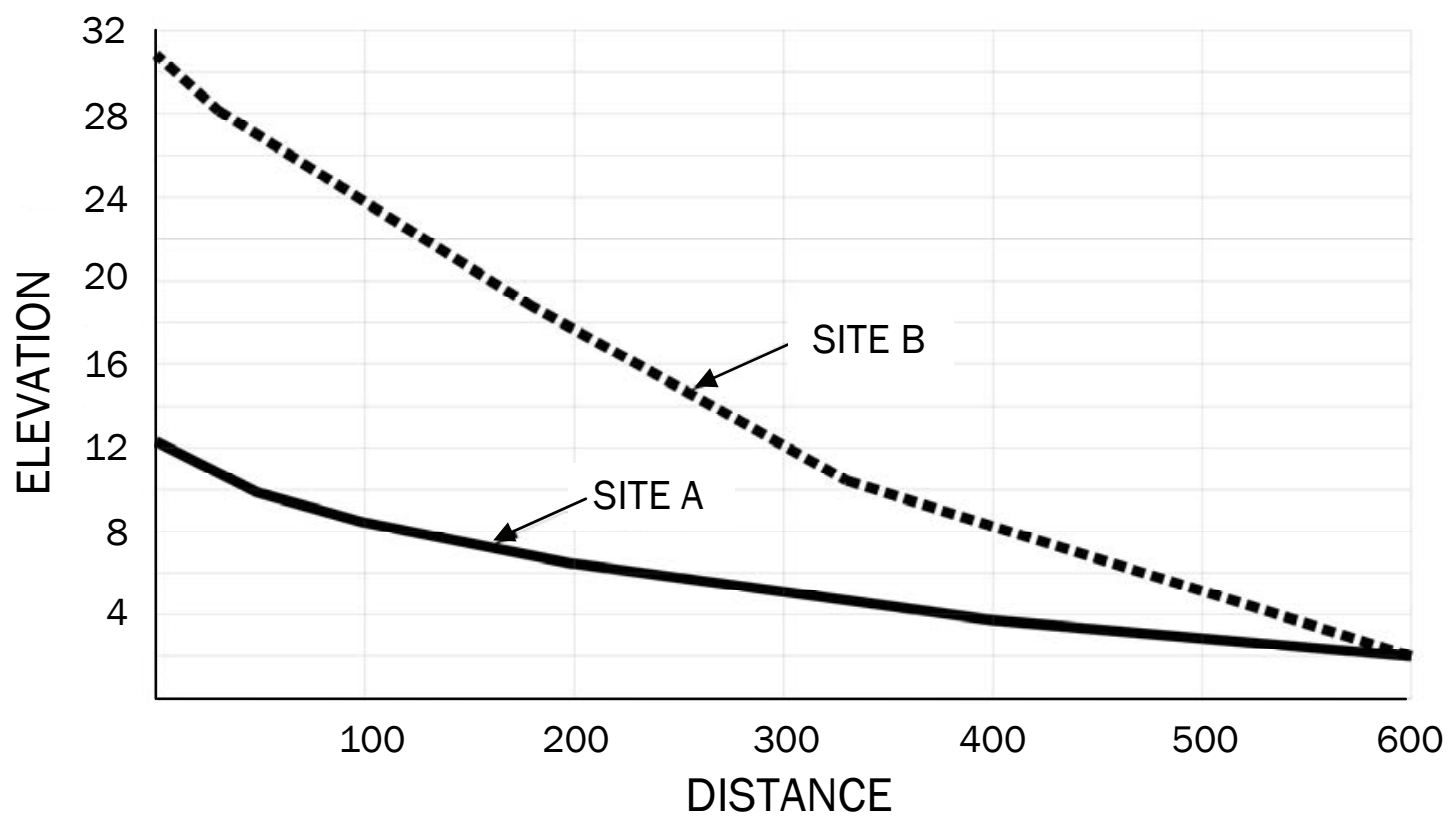

Figure 3 A comparison of the composite curve design profiles of Site A and Site B

The following is evident from Figure 3:

- a noticeably convex beach is formed at both sites

- the advantages of a steeper beach in terms of increased capacity and reduced perimeter embankment raising are clearly evident.

Considering the data in Table 1, it is likely that the higher percentage solids at Site B is the main contributor to a steeper beach. Site B has also reported a significant drop in beaching slopes when the percentage solids drops from 73 to $70 \%$ by mass.

\section{$4 \quad$ Capacity modelling}

The modelling of the final surface of the facilities was an iterative process. The AutoCAD based Surfmate software package was used. The objectives of the capacity modelling for Site A were:

- determine the available capacity with the perimeter embankments at their current elevation

- determine the final height of the perimeter embankments for the life of the facility

- determine the required earthworks volumes for a phased perimeter embankment raise.

The objectives of the capacity modelling for Site B were:

- determine the remaining capacity of Cells 1 and 2 after a single vertical raise of $5 \mathrm{~m}$ along the outer perimeter

- determine the capacity of Cells 1 and 2 after a second raise of $5 \mathrm{~m}$

- determine the timeframe for the construction and commissioning of an additional cell.

The steps involved in the capacity analysis were:

- Step 1: create an outer boundary by modelling raised perimeter embankments. The preferred raising method i.e. upstream, downstream or centre line construction may be applied.

- Step 2: estimate the anticipated final elevation at the deposition tower.

- Step 3: using the composite curve design profiles, create a new surface using three dimensional concentric circles. 
- Step 4: determine the volume between the new and original surface.

- Step 5: repeat steps 2 to 4 until the required volume is achieved.

- Step 6: determine the final elevation of the perimeter embankments allowing for sufficient freeboard.

\subsection{Modelling for Site A}

The surface contours for Site A prior to any embankment raising are as indicated in Figure 4. As Site A has no dedicated return water dam, stormwater runoff migrates to the south western side of the facility. To determine the available capacity of the facility with no perimeter embankment raising, the freeboard limit had to be determined. The freeboard was therefore assessed for two areas:

- water ponding areas (South and South East)

- non water ponding areas (North and East).

For water ponding areas the freeboard was calculated as per the legal requirement in South Africa (GN 704) for tailings storage facilities with centrally located pools:

- 1 in 50 year storm depth $+0.8 \mathrm{~m}$.

The accumulated run-off from the 1 in 50 year storm in the south eastern side of the facility had a depth of approximately $0.8 \mathrm{~m}$. The freeboard limit in this area was therefore calculated as $1.6 \mathrm{~m}$. For non water ponding areas the freeboard limit was reduced and calculated as:

- nominal ponding depth of $0.2 \mathrm{~m}+0.8 \mathrm{~m}=1.0 \mathrm{~m}$.

This principal was also adopted for the modelling of the life of the facility.

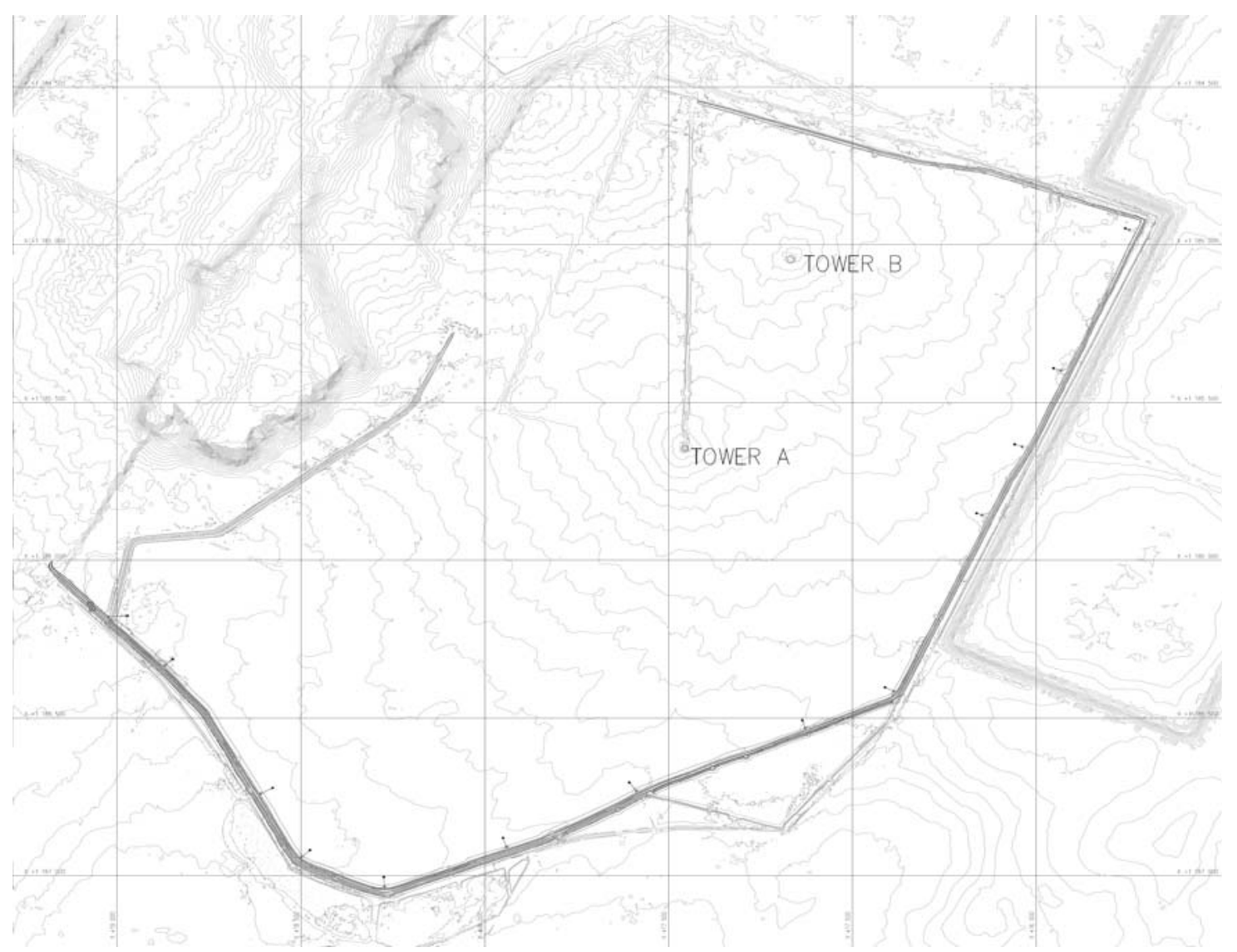

Figure 4 Surface contours for Site A

It is evident from Figure 4 that deposition at Site A is primarily from Tower A. 


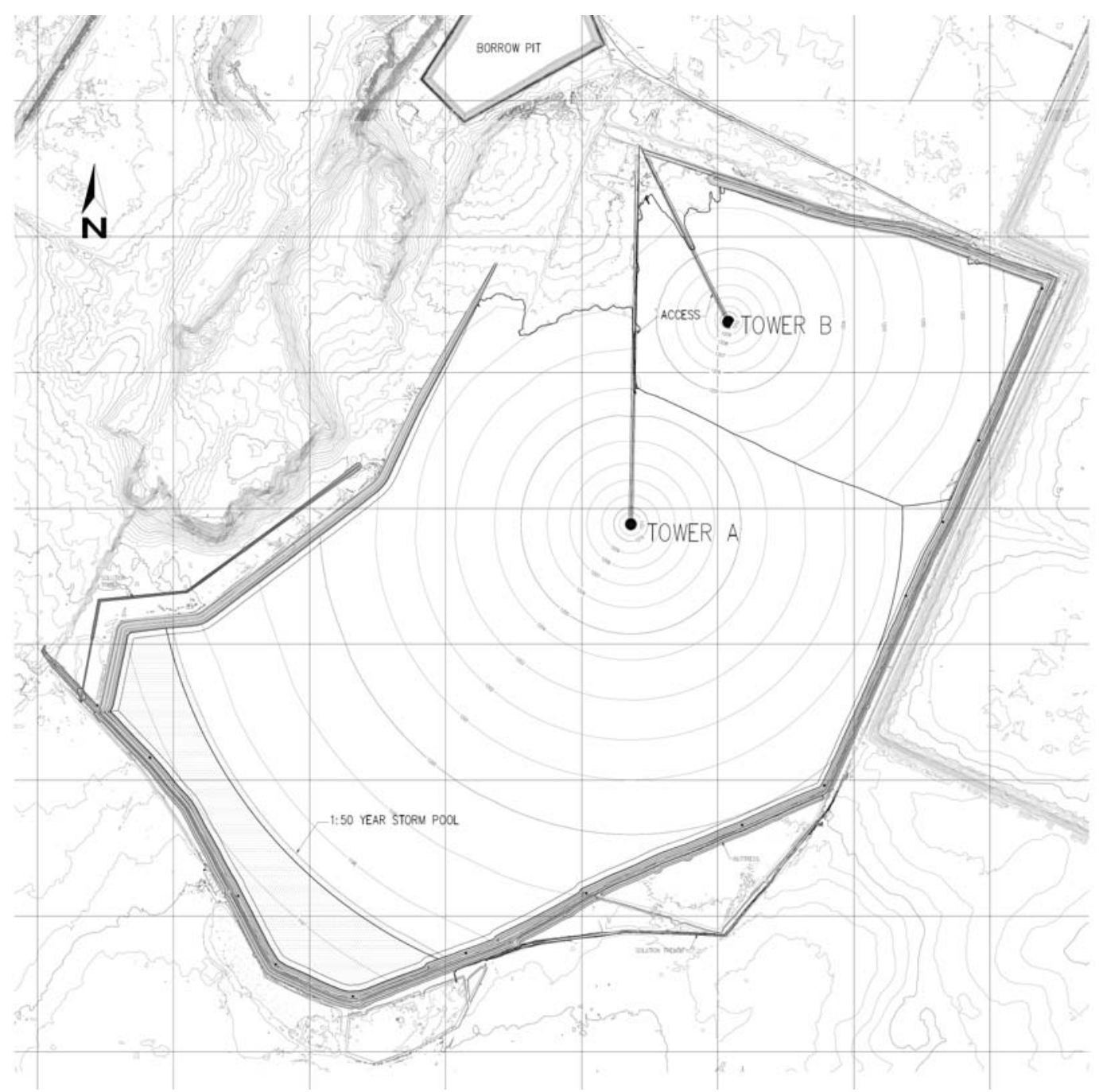

Figure 5 Final modelled surface contours for Site A

As indicated by the contours in Figure 5, the modelling assumes that deposition occurs equally in all directions. As discussed above, both sites have realised the importance of being able to control the direction of deposition. While it is unlikely that deposition will occur equally in all directions it is a fair assumption considering the accuracy of the data and the output required.

\subsection{Modelling for Site B}

The surface contours for Site B during the construction of the first $5 \mathrm{~m}$ perimeter raise are as indicated in Figure 6. Note the intermediate points A and B which have a higher elevation than the original towers. The site slopes down to the east at an average fall of approximately 1:70. Deposition has primarily been on the western side of the facility and this is due to its proximity to the plant which reduces the friction head for pumping. 


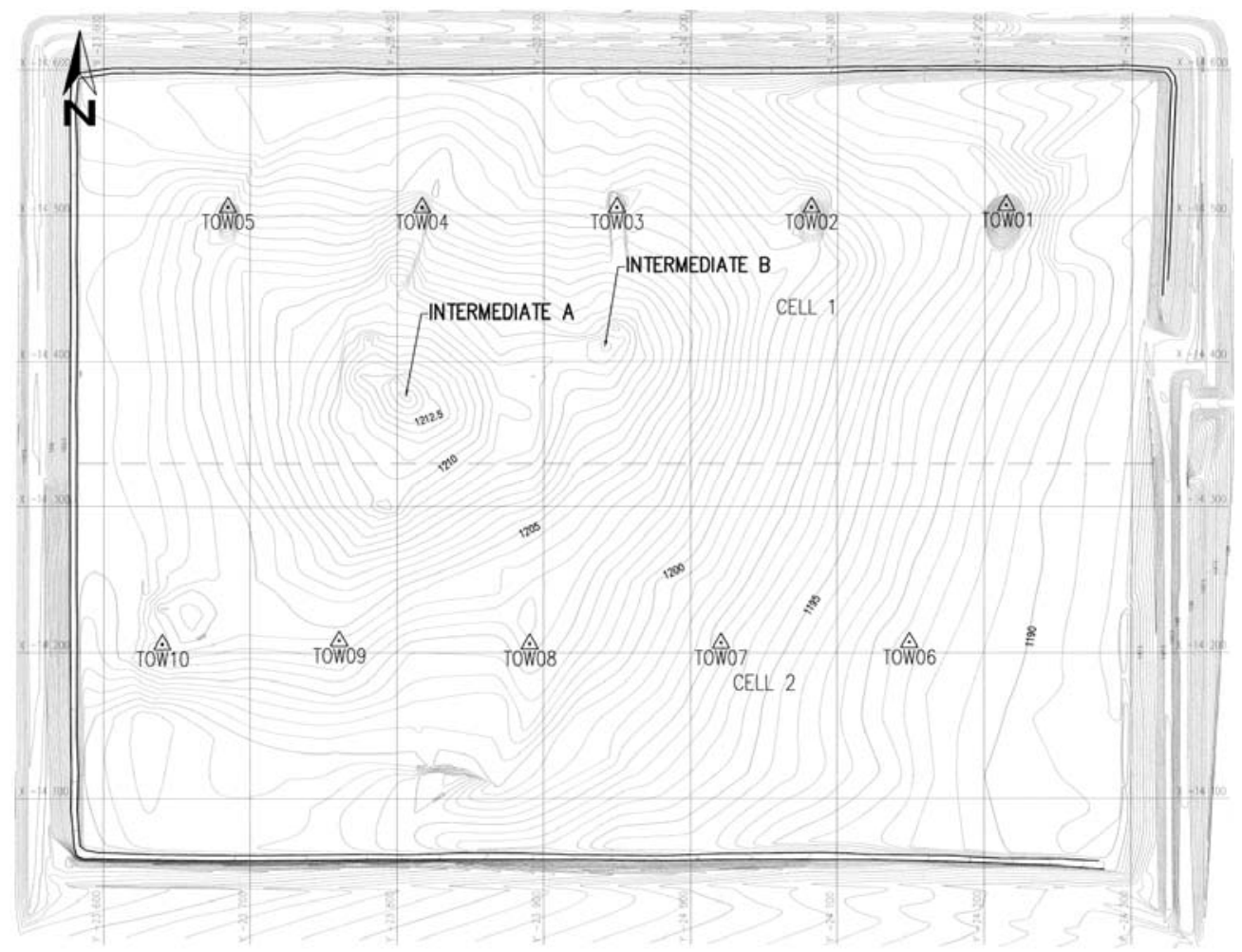

\section{Figure 6 Surface contours for Site B}

The final modelled surface for Site B with the second $5 \mathrm{~m}$ vertical raise is as indicated in Figure 7. It was recommended that the intermediate deposition point $\mathrm{B}$ was moved further south to be in line with intermediate A. The height of the facility is restricted as it is in the mine's flight path. Ideally another intermediate deposition point should be developed to the east of intermediate B and this remains an option if the paste can be pumped there.

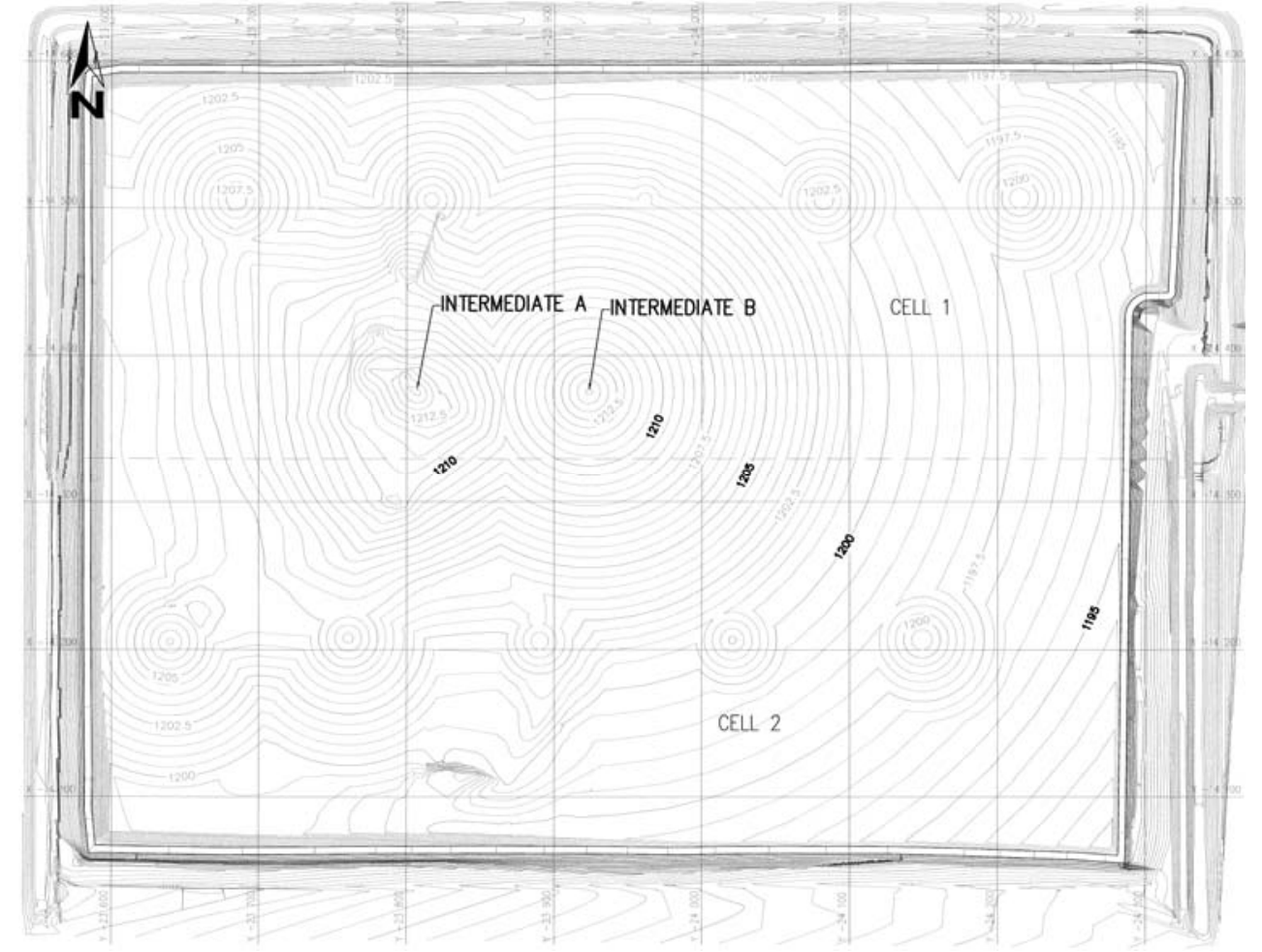

Figure 7 Modelled final surface contours for Site B 


\section{Conclusions}

The beaching slopes of two centrally discharging tailings facilities have been compared. The following conclusions have been made:

- both facilities had a concave beach

- the most important factor in determining the steepness of the beach appears to be the percentage of solids

- as with conventional tailings storage facilities, paste disposal requires cycled deposition in layers this can only be achieved if the direction of deposition is controlled.

A method of determining the future elevations of centrally discharging tailings storage facilities has been proposed. The steps required can be summarised as follows:

- determine the average beaching slopes by taking a number of sections through the deposition points of the facility

- create a composite curve design profile based on the average beaching slopes

- create a three dimensional model of expected future surface of the facility using the design profile. 
